\title{
MEMBENTUK KARAKTER ANTIKORUPSI MELALUI PENDEKATAN MULTIKULTURAL DI MI MAARIF PARAKAN TEMANGGUNG
}

\author{
${ }^{1}$ Rhindra Puspitasari \\ ${ }^{2}$ Bunyamin Maftuh \\ ${ }^{3}$ Elly Malihah
${ }^{1}$ Prodi PIAUD, Jurusan Tarbiyah STAINU Temanggung, email: rhindra.puspitasari@upi.edu
${ }^{2}$ Pendidikan Umum, FKIP, Universitas Pendidikan Indonesia, email: bmafuh@ yahoo.co.id
${ }^{3}$ Pendidikan Ilmu Pengetahuan Sosial, Universitas Pendidikan Indonesia, email: ellyms@upi.edu

\begin{abstract}
Abstrak
Artikel ini mengungkap tentang bagaimana membentuk karakter antikorupsi pada siswa, sehingga dapat memberikan solusi terhadap permasalahan pencegahan tindak pidana korupsi yang sedang menimpa bangsa ini. Adapun tujuan penelitian ini untuk mendeskripsikan pembentukan karakter antikorupsi pada siswa MI Maarif Parakan Temanggung. Penelitian ini merupakan penelitian deskriptif dengan menggunakan pendekatan kualitatif dengan menggunakan metode studi Studi lapangan (Field Research). Dari hasil penelitian ini ditemukan bahwa MI Maarif Parakan Temanggung membentuk karakter antikorupsi dengan pendeketan multikultural melalui pembelajaran di dalam dan diluar kelas. Pembiasaan dan karakter yang ditonjolkan adalah karakter kejujuran dan hidup sederhana. Penanamkan nilai kejujuran dan hidup sederhana yang di lakukan oleh MI Maarif Parakan Temanggung tidak hanya dalam kurikulum yang ada dikelas saja namun juga melalui pembiasaan nyata dengan saling menghargai latar belakang dan budaya di lingkungan sekolah yang dilakukan oleh seluruh elemen sekolah. Hal ini terbukti cukup berhasil dibuktikan dengan adanya penurunan laporan kehilangan yang tercatat di guru bimbingan konseling selama tiga tahun terakhir dan penurunan pertengkaran atau konflik antar siswa. Sehingga langkah nyata yang bisa dilakukan untuk membentuk karakter antikorupsi siswa adalah membiasakan berlaku jujur dan hidup sederhana.
\end{abstract}

Kata kunci: Karakter, antikorupsi dan multikultural

\begin{abstract}
This article reveals how to shape the character of anti-corruption in students, so that it can provide solutions to the problem of preventing corruption that is happening to this nation. The purpose of this study is to describe the formation of anti-corruption character in MI Maarif Parakan Temanggung students. This research is a descriptive study using a qualitative approach using Field Research methods. From the results of this study it was found that MI Maarif Parakan Temanggung formed an anti-corruption character with a multicultural approach through learning inside and outside the classroom. The habits and characters that are highlighted are honesty and simple living. Instilling the value of honesty and simple life that is done by MI Maarif Parakan Temanggung not only in the curriculum in the classroom, but also through real habituation with mutual respect for the background and culture in the school environment that is carried out by all elements of the school. This proved to be quite successful as evidenced by the decrease in reports of losses recorded in counseling guidance teachers during the last three years and a decrease in quarrels or conflicts between students. So that concrete steps that can be taken to shape the student's anti-corruption character are to get used to being honest and living simply.
\end{abstract}


Rhindra Puspitasari, Bunyamin Maftuh, Elly Malihah

Vol 5 No 1

ISSN : 2541-6995

E ISSN : 2580-5517

Keywords: Character, anti-corruption and multicultural

PENDAHULUAN

Pendidikan karakter merupakan salah cara yang cukup efektif untuk mencerdaskan kehidupan bangsa baik dari sisi pengetahuan dan sikap perilaku. Hal ini, merupakan salah satu wujud pelaksanaan tujuan negara Indonesia yang termuat dalam pembukaan alenia ke-4 UUD 1945 Negara Republik Indonesia. Namun, nyatanya pendidikan di Indonesia saat ini dapat dikategorikan masih sangat rendah untuk tingkat kesadaran dalam pendidikan. Secara tersurat maupun tersirat bahwa tujuan pendidikan nasional mengisyaratkan bahwa aspek fisik, sosial, kognitif, efektif dan konatif adalah faktor-faktor keperibadian yang harus di kembangkan melalui pendidikan. Pasal 4 UU No. 2 Tahun 1989 tentang Sistem Pendidikan Nasional mengatakan bahwa

Pendidikan nasional bertujuan mencerdaskan kehidupan bangsa dan megembangkan manusia Indonesia seutuhnya yaitu manusia yang beriman dan bertaqwa terhadap Tuhan yang Maha Esa dan berbudi pekerti yang luhur, memiliki pengetahuan dan keterampilan kesehatan jasmani dan rohani, keperibadian yang mantap dan mandiri serta rasa tanggung jawab kemasyarakat dan kebangsaan (Sisdiknas, 2003). Secara umum tujuan pendidikan untuk mengembangkan kepribadian luhur seseorang mempunyai keterampilan dan pengetahuan serta pekerti yang baik. Program wajib belajar (wajar) 12 tahun ini masih belum berjalan dengan baik, akibatnya proses pendidikan masih jalan di tempat. Selain itu, Program Kartu Indonesia Pintar (KIP) belum tepat sasaran, serta masih banyak masyarakat yang seharusnya layak untuk mendapatkan KIP tapi tidak memperolehnya, asas keadilan dalam dunia pendidikan masih harus dijalankan dengan akuntabilitas dan tanggung jawab. Negara Indonesia adalah negara hukum (UUD 1945, Pasal 1 ayat 3).

Kedaulatan penuh berada ditangan rakyat. Akan tetapi, rakyat hanya digunakan sebagai alat dalam membangun sistem demokrasi yang pada kenyataanya hasil dari perwakilan yang diwakili oleh Dewan Perwakilan Rakyat tidak berjalan sesuai dengan tugas dan harapannya. Rakyat hanya bisa pasrah dengan segala bentuk kekuasaan dan kebijakan pemerintah serta segala bentuk produk peraturan perundang-undangnya, para penguasa dengan leluasanya menciderai amanat rakyat, yang pada akhirnya budaya korupsi, kolusi dan nepotisme terus menjamur di negara Indonesia(Anarki, 2012).

Data dari Indonesia Corruption Watch mencatat, bahwa pada tahun 2017 terdapat 576 kasus korupsi dengan kerugian negara mencapai Rp 6,5 triliun dan suap 
Rhindra Puspitasari, Bunyamin Maftuh, Elly Malihah

Vol 5 No 1

ISSN : 2541-6995

E ISSN : 2580-5517

Rp 211 miliar. Jumlah tersangkanya mencapai 1.298 orang. Berdasarkan rilis ICW, setiap tahun kasus korupsi meningkat pada tahun 2017 mengalami peningkatan signifikan, dan menyebabkan kerugian negara. Sedangkan pada tahun 2016, kerugian negara dari 482 kasus korupsi mencapai Rp 1,5 triliun. Angka ini naik menjadi Rp 6,5 triliun pada tahun 2017 (Kompas, 2018). Pencegahan jika tidak dilakukan mulai dini akan berdampak buruk dan tingkat korupsi setiap tahun akan terus meningkat. Oleh karena itu, siswa Sekolah Dasar menjadi sasaran yang sangat tepat sekali ditanamkan nilai-nilai anti korupsi sejak dini. Terjadi kecenderungan menurunnya akhlaq dan moral yang menyebabkan lunturnya tanggung jawab dan kesetiakawanan sosial, seperti terjadinya tawuran antar pelajar dan kenakalan pelajar bahkan sekarang merambah di tingkat sekolah dasar(Anwar, 2006). Karakter identik dengan kepribadian atau budi pekerti.

Kepribadian adalah ciri, karakteristik, atau sifat khas diri seseorang yang bersumber dari bentukan-bentukan yang diterima dari lingkungan sekitar, misalnya keluarga pada masa kecil dan bawaan sejak lahir (Koesoema, 2007). Pendidikan karakter sejak dini juga merupakan langkah yang tepat untuk menghasilkan sikap anti korupsi. Seperti karakter jujur, religius, dan mandiri sangat mendorong pendidikan pada siswa SD untuk menjauhi dan mencegah berlaku korupsi merupakan bagian perilaku tidak jujur dan curang. Generasi anti korupsi tentu saja bukan merupakan generasi yang muncul secara langsung, tetapi mulai dari proses berupa baik keteladanan serta pembiasaan(Saldi Isra et al, 2017). Penanaman nilai-nilai luhur anti korupsi selain melalui pendidikan formal melalui kegiatan belajar mengajar (KBM) juga dapat dilakukan melalui pendidikan informal seperti pendampinganorang tua serta dukungan lingkungan masyarakat sehingga menjadi insan yang berintegritas.

Pendidikan anti korupsi perlu ditanamkan sejak usia sekolah dasar nilai anti korupsi diintegrasikan ke dalam setiap mata pelajaran. Hal inilah untuk merangsang dari sisi moral siswa, sehingga siswa dapat belajar memahami tentang kegiatan atau perilaku baik atau buruk dan benar atau salah(Arifi, 2009).Undang-undang RI Nomor 20 Tahun 2003 pasal 17 ayat 1 yang menyebutkan bahwa "Pendidikan dasar merupakan jenjang pendidikan yang melandasi jenjang pendidikan menengah." Tujuan dari Pendidikan Dasar adalah meletakan dasar pengetahuan, kepribadian, kecerdasan, akhlaq mulia, serta keterampilan untuk hidup mandiri dan siap mengikuti pendidikan lebih lanjut. Pendidikan antikorupsi sebenarnya sudah menjadi bagian dari pendidikan 
Rhindra Puspitasari, Bunyamin Maftuh, Elly Malihah Vol 5 No 1

ISSN : 2541-6995

E ISSN : 2580-5517

nasional pernyataan dalam peraturan menteri pendidikan nasional tentang standar isi dan standar kompetensi lulusan untuk satuan pendidikan dasar dan menengah. Permendiknas dinyatakan bahwa pengembangan sikap dan perilaku antikorupsi merupakan bagian dari kurikulum bidang studi Pendidikan Kewarganegaraan (PKn) (Permendiknas No 22 dan 23 Tahun 2006). Jadi selain pendidikan Agama, Pendidikan Kewarganegaraan sangat penting sekali untuk menanamkan perilaku anti korupsi.

Berdasarkan pengamatan peneliti di MI Maarif Parakan Temanggung, khususnya yang menyangkut internalisasi nilai-nilai anti korupsi masih belum menunjukan metode pembelajaran yang menjelaskan pentingnya pendidikan anti korupsi. Metode pembelajaran yang terjadi, masih terkonsentrasi pada pembentukan kognisi melalui pemberian informasi secara verbal (ceramah), tanpa ada metode pembelajaran secara mendalam di dalam KBM seperti active learning, sehingga kurang adanya innovatif dan kreatif. Menurut keterangan Kepala Sekolah MI Maarif Parakan Temanggung diperlukan sebuah metode pembelajaran yang tepat untuk diaplikasikan dalam setiap mata pelajaran sebagai upaya membentuk karakter anti korupsi. Internalisasi anti korupsi di MI Maarif Parakan Temanggung sebagai upaya untuk membentuk kepribadian pekerti luhur dan paling utama adalah dapat melatih peserta didik menanamkan sembilannilai-nilai antikorupsi yakni kejujuran, tanggung jawab, disiplin, kerja keras, adil, mandiri, pemberani, dan sederhana.

Berdasarkan hal tersebut, penulis tertarik untuk menemukan metode pembelajaran yang tepat dengan mengaitkan internalisasi nilai-nilai antikorupsi disetiap mata pelajaran. Sehingga sekolah dalam pembelajaran maksimal, seperti kegiatan pembelajaran intrakurikuler buktinya ada siswa yang menemukan uang jatuh di area sekolahan siswa tersebut langsung melaporkannya kepada guru, kemudian terlihat dari ujian ulangan baik tengah semester maupun ujian kenaikan kelas tidak banyak yang mencontek. Selain itu,saat ini sudah banyak siswa yang berani untuk tampil di depan kelas dalam materi pelajaran bercerita atau mengerjakan soal-soal yang diberikan oleh guru. Untuk sisi ko kurikulernya dilaksanakan seperti pengayaan mata pelajaran, kegiatan ilmiah, pembimbingan seni dan budaya, dan penguatan karakter siswa.

Seperti mengagendakan mengunjungi tempat edukasi di museum nasional termasuk tempat-tempat bersejarah. Selain itu, siswa dilibatkan dengan membuat jadwal membersihkan kelas secara bergantian dan gotong royong. Ekstrakurikuler 
Rhindra Puspitasari, Bunyamin Maftuh, Elly Malihah Vol 5 No 1

ISSN : 2541-6995

E ISSN : 2580-5517

dilaksanakan melalui senam pada setiap hari jumat dengan gerakan-gerakan yang berisi mengenai pesan-pesan yang dapat membentuk karakter siswa. Selain itu, untuk melatih kedisiplinan, khususnya untuk siswa kelas III sampai kelas VI dilibatkan dalam kegiatan pramuka yang dilaksanakan satu kali dalam sebulan. Untuk penguatan iman dan moral dengan menerapkan untuk sholat dhuha dan hapalan juz amma di setiap harinya.

Dari uraian di atas, maka penulis tertarik untuk melakukan penelitian dengan judul membentuk karakter anti korupsi siswa Madrasah Ibtidaiyah Al Maarif Parakan Temanggung."'Berdasarkan latar belakang masalah di atas maka dapat dirumuskan sebagai berikut: Bagaimanakah membentuk karakter anti korupsi yang sudah diterapkan pada siswa MI Maarif Parakan Temanggung.

\section{METODE PENELITIAN}

Penelitian ini adalah penelitian deskriptif dengan menggunakan pendekatan kualitatif studi kasus di MI Maarif Parakan Temanggung. Penelitian ini di lakukan pada bulan Juni-Desember 2019. Penentuan subjek penelitian dalam penelitian ini menggunakan teknik purposive sampling, dengan kriteria subjek yang mengetahui, berpengalaman, serta memberikan informasi. Kepala sekolah sebagai sebyek yang akan menjelaskan mengenai kegiatan belajar mengajar yang dilaksanakan oleh guru di setiap kelas, kemudian guru sebagai subyek yang akan menjelaskan mengenai kegiatan belajar mengajar yang telah dilaksanakan sampai saat ini, serta sebagian dari siswa MI Maarif Temanggung kelas I -VI yang akan menjelaskan sejauh mana yang dilaksanakan siswa tersebut dalam kegiatan sehari-hari. Peneliti menggunakan beberapa teknik untuk mengumpulkan data, yaitu dengan wawancara (interview)terhadap responden dan studi kepustakaan melalui penelusuran data dokumen dan observasi. Data yang sudah diperoleh, kemudian dilakukan pengolahan dengan kemudian dilakukan pemeriksaan keabsahannya agar diperoleh data yang dapat dipertanggungjawabkan secara ilmiah dengan teknik trianggulasi. Adapun teknik analisis datanya adalah teknik perolehan data secara originalitas data dengan dilakukan diskusi disetiap perolehan datanya.

\section{HASIL PENELITIAN DAN PEMBAHASAN}

\section{Hasil Penelitian}

Berdasarkan hasil wawancara dengan Kepala Sekolah MI Maarif Parakan Temanggung, Pendidikan antikorupsi dilakukan dengan pendekatan multikultural baik dalam pembelajaran maupun pembiasaan dan pembentukan budaya sekolah. Guru dan 
Rhindra Puspitasari, Bunyamin Maftuh, Elly Malihah Vol 5 No 1

ISSN : 2541-6995

E ISSN : 2580-5517

Kepala Sekolah sepakat bahwa korupsi adalah suatu tindakan ketidakjujuran, hal ini penting dicegah sedini mungkin. Hal ini sesuai dengan yang disampaikan Abdulloh, bahwa penting menanamkan karakter anti korupsi sejak usia sekolah dasar(Abdulloh, 2017). Pendidikan antikorupsi berhubungan sangat erat dengan pengembangan ranah kognitif, afektif dan psikomotor siswa yang wajib diperkenalkan sejak dini yakni pada sekolah dasar. Hal ini dilakukan untuk penanaman dan penguatan nilai-nilai dasar dalam membentuk sikap anti korupsi pada diri siswa yang diaplikasikan dalam setiap mata pelajaran.Undang-Undang Republik Indonesia Nomor 20 Tahun 2003 tentang Sistem Pendidikan Nasional (Sisdiknas) telah merumuskan fungsi dan tujuan pendidikan nasional. Pasal 3 UU tersebut menyatakan: "Pendidikan nasional berfungsi mengembangkan kemampuan dan membentuk watak serta peradaban bangsa yang bermartabat dalam rangka mencerdaskan kehidupan bangsa, bertujuan untuk berkembangnya potensi peserta didik agar menjadi manusia yang beriman dan bertaqwa kepada Tuhan YME, berakhlak mulia, sehat, berilmu, cakap, mandiri, dan menjadi warga negara yang demokratis serta bertanggung jawab."

Pendidikan karakter merupakan penciptaan lingkungan sekolah yang membantu siswa dalam pengembangan etika, tanggung jawab melalui metode pembalajaran dan pengajaran karakter yang baik melalui nilai-nilai universal(Maria M, 2012). Rumusan komisi pemberantasan korupsi (KPK) perlu ada sembilan nilai dasar yang ditanamkan dan diperkuat melalui pelaksanaan pendidikan anti korupsi di sekolah, yaitu nilai kejujuran, adil, berani, hidup sederhana, tanggung jawab, disiplin, kerja keras, hemat dan mandiri(Shobirin, 2017). Hasil temuan di MI Maarif Parakan Temanggung menunjukkan, karakter kejujuran dan hidup sederhana sangat menonjol, seperti yang di sampaikan Kepala Sekolah MI Maarif Parakan. Di MI Maarif Parakan Temanggung penanaman karakter kejujuran dan hidup sederhana sangat digiatkan. Terutama dalam pembelajaran dalam kelas dan melalui pembiasaan di lingkungan sekolah. Sehingga penanaman karakter kejujuran yang mendukung penidikan antikorupsi juga digalakkan di MI Maarif Parakan Temanggung. Pembiasaan dilingkungan sekolah yang akhirnya membentuk budaya antikorupsi.

Dari data yang ada di BK menunjukkan adanya penurunan catatan laporan kehilangan dan pertengkaran siswa akibat konflik seperti tergambar pada Tabel 1 dan 2 di bawah ini. 
Tabel 1 Rekap Laporan Kehilangan Siswa 2015-2019

\begin{tabular}{lll}
\hline No. & Tahun & Jumlah \\
\hline 1. & 2015 & 131 \\
2. & 2016 & 135 \\
3. & 2017 & 120 \\
4. & 2018 & 96 \\
5 & 2019 & 58 \\
\hline
\end{tabular}

Sumber: Laporan Guru BK 2019

Kasus perkelahian akibat konflik siswa juga mengalami penurunan yang bisa dilhat pada Tabel 2 berikut:

Tabel 1 Rekap Laporan Perkelahian Siswa 2015-2019

\begin{tabular}{lll}
\hline No. & Tahun & Jumlah \\
\hline 1. & 2015 & 97 \\
2. & 2016 & 95 \\
3. & 2017 & 86 \\
4. & 2018 & 70 \\
5 & 2019 & 55 \\
\hline
\end{tabular}

Sumber: Laporan Guru BK 2019

Dari hasil observasi dan wawancara dengan guru kelas menjelaskan bahwa semenjak dilakukan pendekatan multikultural dalam pembelajaran dan pembiasaan disekolah siswa menjadi lebih memiliki sikap saling menghargai dan toleransi. Pendekatan multikultural yang dilakukan guru diantaranya dengan mendongeng, melihat pentas budaya, bermain peran dan berdiskusi.

\section{Pembahasan}

Ketika membaca fungsi dan tujuan pendidikan nasional, jelas disebutkan bahwa pendidikan di setiap jenjang, termasuk yang utama adalah SD harus diselenggarakan secara sistematis guna mencapai tujuan tersebut. Ini berkaitan dengan pembentukan karakter peserta didik sehingga mampu bersaing, beretika, bermoral, sopan santun dan berinteraksi dengan masyarakat. Menurut pernyataan dari kepala sekolah MI Maarif Parakan Temanggung, Jawa Tengah, baik untuk siswa kelas I maupun kelas VI membentuk karakter antikorupsi dilakukan dengan menginternalisasi nilai-nilai antikorupsi. Internalisasi nilai-nilai anti korupsi sudah dilakukan oleh guru wali kelas untuk setiap mata pelajaran namun belum maksimal. Beliau juga menyatakan untuk semua guru wali kelas diwajibkan setiap kegiatan belajar mengajar dengan 
Rhindra Puspitasari, Bunyamin Maftuh, Elly Malihah Vol 5 No 1

ISSN : 2541-6995

E ISSN : 2580-5517

memasukkan nilai-nilai anti korupsi. Untuk penerapan pembelajaran kelas I-III MI menggunakan metode dongeng. Metode Dongeng Tokoh Pahlawan Nasional bisa dihayati dalam proses internalisasi nilai antikorupsi. Dilakukan sebagai upaya mengingat tindakan-tindakan yang dilarang maupun tindakan-tindakan yang diperbolehkan.

Sedangkan untuk kelas IV sampai kelas VI penerapannya lebih kepada hal-hal teknis/praktek dalam kesehariannya. Hal ini juga dibenarkan oleh wakil Kepala Sekolah, memang benar penanaman anti korupsi ini sangat diperlukan dalam melatih moral dan karakter anak. Sedangkan menurut Wali Kelas V, saat ini siswa kelas V sudah banyak yang terbentuk karakternya dari internalisasi anti korupsinya, buktinya ada siswa yang menemukan uang jatuh di area sekolahan siswa tersebut langsung melaporkannya kepada guru, contoh lain terlihat dari ujian ulangan baik tengah semester maupun ujian kenaikan kelas tidak banyak yang mencontek. Selain itu, untuk saat ini sudah banyak siswa yang berani untuk tampil di depan kelas dalam materi pelajaran bercerita atau mengerjakan soal-soal yang diberikan oleh guru(Sumiati, 2007).

Hal inilah sudah menunujukkan beberapa nilai penting daripada pendidikan anti korupsi sejak dini. Selain kegiatan intrakurikuler yang diterapkan di MI Maarif Parakan Temanggung, ada kegiatan kokurikuler untuk menguatkan kegiatan intrakurikuler seperti pengayaan mata pelajaran, kegiatan ilmiah, pembimbingan seni dan budaya, dan penguatan karakter siswa. Seperti mengagendakan mengunjungi tempat edukasi di museum nasional termasuk tempat-tempat bersejarah. Selain itu, siswa dilibatkan dengan cara membuat jadwal membersihkan kelas secara bergantian dan gotong royong.

Melalui kegiatan mendongeng tersebut anak diedukasi tentang hikmah dari kejujuran dan sikap hidup sederhana dari tokoh yang ada pada dongeng tersebut. Sedangkan melalui kegiatan kokulikuler siswa diajak membiasakan diri hidup sederhana dan saling- tolong menolong. Menggambil semangat para tokoh dan diperkenalkan tempat-tempat bersejarah dan mengambil hikmah dari tempat tersebut, kemudian dipraktekkkan di lingkungan sekolah.

Pelaksanaan pendidikan karakter melalui sebuah kegiatan di luar jam sekolah ditempuh melalui dua cara. Pertama, melalui suatu kegiatan ekstrakurikuler yang dikelola oleh pihak sekolah dengan seorang penanggung jawab. Kedua, melalui 
Rhindra Puspitasari, Bunyamin Maftuh, Elly Malihah Vol 5 No 1

ISSN : 2541-6995

E ISSN : 2580-5517

kemitraan dengan lembaga lain yang memiliki kapabilitas dalam pembinaan karakter. Ekstrakurikuler merupakan kegiatan yang lebih bersifat kepada pengembangan potensi, bakat, minat siswa dan pengembangan diri siswa seperti senam atau olah raga, seni, dan pemahaman keagamaan sebagaimana kegiatan ekstrakurikuler termuat dalam Pasal 5 ayat (5) Peraturan Menteri Pendidikan dan Kebudayaan Nomor 23 Tahun 2017 tentang Hari Sekolah.

MI Maarif Parakan Temanggung selalu melakukan senam pada setiap hari jumat dengan gerakan-gerakan yang berisi mengenai pesan-pesan yang dapat membentuk karakter siswa. Selain itu, untuk melatih kedisiplinan, khususnya untuk siswa kelas III sampai kelas VI dilibatkan dalam kegiatan pramuka yang dilaksanakan satu kali dalam sebulan. Untuk penguatan iman dan moral dengan cara menerapkan untuk sholat dhuha dan hapalan juz amma di setiap harinya. Hal ini dilakukan sebagai bentuk untuk menguatkan karakter siswa melalui pembiasaan yang baik.

Pembiasaan yang dilakukan baik di dalam kelas maupun diluar kelas yang dilakukan secara terus-menurus akhirnya membentuk suatu budaya sekolah(Nicole\&Susanne, 2017). Budaya sekolah antikorupsi menurut Ibu Sri Hamdanah selaku kepala sekilah MI M sudah diupayakan sejak tiga tahun terakhir ini. Dengan menanamkan karakter kejujuran dan hidup sederhana serta pembiasaan akhlak mulia dilatihkan secara terus-menerus. Elemen yang seperti inilah yang wajib untuk diterapkan dalam menginternalisasi nilai-nilai anti korupsi.

Proses dan hasil upaya pendidikan yang seperti ini tidak akan terlihat dalam waktu yang cepat, namun membutuhkan waktu yang panjang(Sabran, 2018). Sehingga hal ini memang perlu dilakukan secara berkala dan berkelanjutan dan mampu untuk menangkal terhadap setiap permasalahan dan tantangan yang datang. Pendidikan semacam inipun dapat berpengaruh terhadap mutu penyelenggaraan dan hasil pendidikan di sekolahan yang mengarah pada pencapaian pembentukan karakter dan akhlaq mulia siswa secara utuh sesuai dengan standar kompetensi lulusan yang berujung pada peningkatan peminatan siswa didik baru.

Hal ini dapat dilakukan dengan cara membiasakan anak untuk bersosialisasi dan berinteraksi dengan lingkungan sekitar, karena lingkungan sangat menentukan pembentukan karakter si anak. MI Maarif Parakan Temanggung berdasarkan keterangan dari kepala sekolah, hampir setiap awal tahun pembelajaran baru selalu ada konseling antara sekolahan dengan wali murid/siswa yang di dalamnya membahas 
Rhindra Puspitasari, Bunyamin Maftuh, Elly Malihah Vol 5 No 1

ISSN : 2541-6995

E ISSN : 2580-5517

mengenai kegiatan belajar mengajar, peran wali murid di kesehariannya terhadap siswa. Sehingga harapan kedepannya selain karakter antikorupsi itu membudaya di lingkungan sekolah tapi juga di lingkungan keluarga dan masyarakat.

\section{KESIMPULAN DAN IMPLIKASI}

Membentuk karakter antikorupsi yang telah dilakukan di MI Maarif Parakan Temanggung adalah dengan melalui pembelajaran di dalam dan diluar kelas. Pembiasaan dan karakter yang ditonjolkan adalah karakter kejujuran dan hidup sederhana. Guru dan seluruh elemen sekolah dibentuk untuk selalu berlaku jujur dan hidup sederhana. Kepala sekolah mewajibkan semua guru dan elemen sekolah untuk memasukkan nilai-nilai kejujuran tidak hanya dalam mata pelajaran yang di ajarkan di kelas, tapi juga pada-pada kegiatan di luar kelas. Tidak hanya nilai kejujuran namun juga kebiasaan hidup sederhana juga dibudaya di MI Maarif ini. Sekolah bersinergi dengan wali murid an lingkungan masyarakat untuk membentuk karakter hidup sederhana ini. Walaupun membutuhkan proses yang cukup lama namun pembentukan karakter antikorupsi dengan membudayakan nilai kejujuran dan hidup sederhana cukup berhasil dilakukan di MI Maarif Parakan Temanggung Temanggung. Hal ini dibuktikan dengan sikap jujur anak saat ulangan maupun kegiatan lain, jarang terjadi laporan kehilangan dari siswa dan guru yang tercatat di BK selama tiga tahun terakhir. Inilah yang menjadi pembeda MI Maarif Parakan Temanggung dengan sekolah lainnya. Karena membudayakan nilai antikorupsi dengan cara menanamkan nilai kejujuran dan hidup sederhana tidak hanya dalam kurikulum yang ada dikelas saja namun juga melalui pembiasaan nyata di lingkungan sekolah yang dilakukan oleh seluruh elemen sekolah.

\section{DAFTAR PUSTAKA}

Anarki, Jiwo Damar. (2012). Menanti Hadirnya Generasi Anti Korupsi, dalam buku kumpulan essay, Resa S. Zaki (ed), Negeri Melawan Korupsi. Yogjakarta: Bulaksumur Visual.

Anwar, Syamsul, (2006), Fikih Antikorupsi Perspektif Ulama Muhammadiyah Majelis Tarjih dan Tajdid PP Muhammadiyah, Jakarta: Pusat studi Agama dan Peradaban (PSAP).

Arifi, Ahmad. (2009). Politik Pendidikan Islam, Menelusuri Ideologi dan aktualisasi Pendidikan Islam di Tengah Arus Globalisasi. Yogyakarta: TERAS.

Koesoema, Doni. (2007). Pendidikan Karakter: Strategi Mendidik Anak di Zaman Global. Jakarta: Grasindo. Cet. I. 


\section{Jurnal}

E ISSN : 2580-5517

Abdulloh Hadziq. (2017). Konsepsi Pendidikan Agama Anti Korupsi di Sekolah Dasar. Jurnal Edukasi STAIN Kudus. Vol. 5 / No. 2 / Juli-Desember 2017.

Maria Montessori.( 2012). Pendidikan Antikorupsi Sebagai Pendidikan Karakter di Sekolah. Jurnal Ilmiah Politik Kenegaraan. UNP. Vol 11, No 1 (2012).

Nicole Duerrenberger \& Susanne Warning. (2017). Corruption and education in developing countries: The role of public vs. private funding of higher education. International Journal of Educational Development 62 (2018) 217-225.

Sabran, O. Sihombing. (2018). Youth perceptions toward corruption and integrity: Indonesian context.Kasetsart Journal of Social Sciences 39 (2018) 299e304.

Saldi Isra et al. (2017). Obstruction of justice in the effort to eradicate corruption in Indonesia.International Journal of Law, Crime and Justice 51 (2017) 72e83.

Shobirin, Ma'as. (2017). Model penanaman nilai-nilai anti korupsi di Sekolah Dasar.Jurnal Ilmiah Pendidikan Dasar UNISSULA (Pendas). Vol. IV No.1 Januari 2017.

Sumiarti. (2007). Pendidikan Anti Korupsi. Jurnal INSANIA. STAIN Purwokerto. Vol. 12|No. 2|MeiAgs 2007.

\section{Perundang-undangan}

Undang-Undang Dasar Negara Republik Indonesia Tahun 1945

Undang Undang Nomor 20 Tahun 2003 tentang Sistem Pendidikan Nasional

Permendiknas No.22 dan No. 23 Tahun 2006 tentang Standar Isi Dan Standar Kompetensi Lulusan Untuk Satuan Pendidikan Dasar Dan Menengah

Undang-Undang No. 30 Tahun 2002 Tentang Komisi Pemberantasan Korupsi

Undang-Undang Republik Indonesia Nomor 20 Tahun 2001 Tentang Perubahan Atas Undang-Undang Nomor 31 Tahun 1999 Tentang Pemberantasan Tindak Pidana Korupsi.

\section{Internet}

Kompas, 2018, Tren Modus Korupsi 2017 Versi ICW. https://nasional.kompas.com/read/2018/02/20/07542211/tren-modus-korupsi-2017-versi-icw. 18 Juni 2018 (11:24 WIB). 